\title{
MUSYARAKAH MUTANAQISHAH
}

\author{
'Ainul Imronah \\ STAI Sufyan Tsauri Majenang Cilacap \\ Email:aizuhdi7@gmail.com
}

Abstract: The expense and finance are products which are issued by sharia financial institutions, includingmusharakamutanaqishah. Musharakamutanaqishah is a form of cooperation between two or more parties for the ownership of goods or assets. This cooperation will reduce the ownership rights of one party while the other party increases its ownership rights. This article is purposed to give knowledge to whom do not understand well about Musyarakahmutanaqishah. The nature of the research is descriptive which used literature study in collecting the data. The technique of Data analysis is used qualitative analysis. The results of the study are the definition, the history and the root of musyarakahmutanaqishah, the provision of musyarakahmutanaqishah law, the terms of the contract, the provisions of the related parties, the criteria of the customer, the financing scheme, the advantages and the weaknesses of Musyarakahmutanaqishah, the ownership of syirkah modality and the ending of syirkah.

Keyword:Musyarakahmutanaqishah, financing, sharia bank

\begin{abstract}
Abstrak: Pendanaan dan pembiayaan adalah produk yang dikeluarkan lembaga keuangan syariah. Termasuk musyarakah mutanaqishah. Musyarakah mutanaqishah adalah bentuk kerjasama antara dua pihak atau lebih untuk kepemilikan barang atau asset. Dimana kerjasama ini akan mengurangi hak kepemilikan salah satu pihak sementara pihak yang lain bertambah hak kepemilikannya.Tujuannya penulisan ini adalah untuk menambah edukasi kepada masyarakat yang belum paham betul musyarakah mutanaqishah. Sifat penelitian adalah deskriptif, dengan teknik pengumpulan data studi pustaka. Teknik analisis data menggunakan analisis kualitatif. Hasil kajian yang diperoleh adalah definisi, sejarah dan akar akad musyarakah mutanaqishah, ketentuan hukum musyarakah mutanaqishah, ketentuan akad, ketentuan pihak terkait, kriteria nasabah, skema pembiayaan, kelebihan dan kelemahan pembiayaan musyarakah mutanaqishah, status kepemilikan modal usaha syirkah dan berakhirnya syirkah.
\end{abstract}

Kata kunci:Musyarakah Mutanaqishah, Pembiayaan, Lembaga Keuangan Syariah

\section{A. PENDAHULUAN}

Dewasa ini perkembangan produkproduk perbankan syariah semakin banyak dan berkembang. Dari mulai produk pengumpulan dana sampai pada pembiayaan usaha mikro ataupun makro. Semakin banyak yang dikaji maka semakin banyak pula pemikiranpemikiran yang muncul tentang pembiayaan perbankan syariah.

Dibanding pembiayaan berbasis bagi hasil, pembiayaan akad jual beli juga dinilai berisiko lebih rendah. Aspek risiko itulah yang menjadi salah satu penyebab kurang berkembangnya produk berakad bagi hasil. Oleh karena itu, untuk meningkat

kan pembiayaan bagi hasil sejumlah akad terus dieksplorasi, salah satunya adalah musyarakah mutanaqisah (MMq).

Kajian terhadap produk $\mathrm{MMq}$ sebagai varian produk bagi hasil dan alternatif yang mempunyai daya saing telah dilakukan sejak 2008. Akad tersebut juga sudah masuk dalam Kodifikasi Produk Perbankan Syariah Internasional Direktorat Perbankan Syariah Tahun 2008 dan memperoleh fatwa DSN MUI di tahun yang sama. Berikut penulis akan membahas tentang produk pembiayaan musyarakah mutanaqishah. 


\section{B. PEMBAHASAN}

\section{Definisi Musyarakah Mutanaqishah}

Al Musyarakah merupakan salah satu instrumen yang dipergunakan oleh perbankan syariah untuk menyediakan pembiayaan. Dalam bahasa indonesia, ia diterjemahkan dengan kemitraan atau persekutuan atau perkongsian, dan dalam ranah ilmu ekonomi, ia terkait dengan teori percampuran. Teori ini menyangkut dua pilar: objek percampuran dan waktu percampuran. Sama seperti yang terdapat dalam teori percampuran, ilmu fiqh membedakan dua jenis objek percampuran. Pertama, objek campuran 'ain (real asset) berupa barang dan jasa yang meliputi: a) percampuran antara 'ain dan 'ain atau real asset dengan real asset; dan b) percampuran antara real asset dan finacial asset. Kedua, percampuran antara financial asset dan financial asset. Dari sisi waktu terjadinya percampuran, ilmu fiqh mengelompokan waktu percampuran atas dua waktu, penyerahan saat itu juga atau naqdan dan penyerahan yang ditangguhkan atau muajjal. ${ }^{1}$

1 Atang Abdul Hakim, Fiqh Perbankan Syariah: Transformasi Fiqh Muamalah ke dalam Peraturan Perundang-undangan, (Bandung: Refika Aditama, cetakan kesatu September 2011), hal. 244.
Dalam istilah fiqh terdapat tiga istilah tentang pengertian percampuran, kemitraan, persekutuan, dan perkongsian yaitu al musyarakat, syirkah, dan syarikat. Dalam bukunya Atang Abdul Hakim yang lebih tepat dari ketiga istilah itu ialah syirkat, oleh karena itu, literatur ilmu figh lebih banyak menggunakan istilah ini sedangkan peraturan perbankan syariah mempergunakan istilah musyarakah. ${ }^{2}$

Musyarakah Mutanaqishah merupakan bagian atau bisa juga kelanjutan dari musyarakah. ${ }^{3}$ Musyarakah merupakan istilah yang sering dipakai dalam konteks skim pembiayaan Syariah. Istilah ini berkonotasi lebih terbatas daripada istilah syirkah yang lebih umum digunakan dalam fikih Islam. Syirkah berarti sharing 'berbagi', dan dalam terminologi Fikih Islam dibagi dalam dua jenisyaitu Syirkah al-milk atau syirkah amlak atau syirkah kepemilikan, yaitu kepemilikan bersama dua pihak atau lebih dari suatu properti; danSyirkah al-'aqad atau syirkah 'ukud atau syirkah akad, yang berarti kemitraan yang terjadi

\footnotetext{
${ }^{2}$ Ibid.

${ }^{3}$ Ascarya, Akad dan Produk Bank Syariah, (Jakarta:Raja Grafindo Persada, cetakan ke III 2011), hal. 49.
} 
karena adanya kontrak bersama, atau usaha komersial bersama.

Sementara mutanaqishah berasal dari kata yatanaqishu-tanaqishtanaqishan-mutanaqishun yang berarti mengurangi secara bertahap. Firman Allah SWT : 4

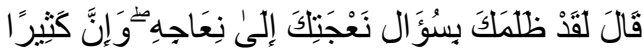

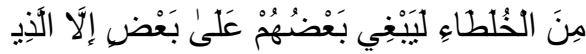

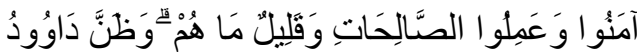

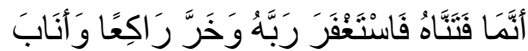

“......dan Sesungguhnya kebanyakan dari orang-orang yang berserikat itu sebahagian mereka berbuat zalim kepada sebahagian yang lain, kecuali orang-orang yang beriman dan mengerjakan amal yang saleh; dan Amat sedikitlah mereka ini". (QS: Shaad : 24)

\section{Musyarakah mutanaqishah}

(diminishing partnership) adalah bentuk kerjasama antara dua pihak atau lebih untuk kepemilikan suatu barang atau asset. Dimana kerjasama ini akan mengurangi hak kepemilikan salah satu pihak sementara pihak yang lain bertambah hak kepemilikannya. Perpindahan kepemilikan ini melalui mekanisme pembayaran atas hak kepemilikan yang lain. Bentuk kerjasama ini berakhir dengan pengalihan hak salah satu pihak kepada pihak lain.

4 Lihat fatwa DSN-MUI No.73/DSNMUI/XI/2008 tentang Musyarakah Mutanaqishah
Dalam fatwa DSN No: 73/DSNMUI/XI/2008 yang dimaksud Musyarakah Mutanaqishah adalah Musyarakah atau Syirkah yang kepemilikan asset (barang) atau modal salah satu pihak (syarik ${ }^{5}$ ) berkurang disebabkan pembelian secara bertahap oleh pihak lainnya.

Implementasi dalam operasional perbankan syariah adalah merupakan kerjasama antara bank syariah dengan nasabah untuk pengadaan atau pembelian suatu barang (benda). Dimana asset barang tersebut jadi milik bersama. Adapun besaran kepemilikan dapat ditentukan sesuai dengan sejumlah modal atau dana yang disertakan dalam kontrak kerjasama tersebut. Selanjutnya nasabah akan membayar (mengangsur) sejumlah modal/dana yang dimiliki oleh bank syariah. Perpindahan kepemilikan dari porsi bank syariah kepada nasabah seiring dengan bertambahnya jumlah modal nasabah dari pertambahan angsuran yang dilakukan nasabah. Hingga angsuran berakhir berarti kepemilikan suatu barang atau benda tersebut sepenuhnya menjadi milik nasabah. Penurunan porsi kepemilikan bank

${ }^{5}$ Syarik adalah mitra, yakni pihak yang melakukan akad syirkah (musyarakah). 
syariah terhadap barang atau benda berkurang secara proporsional sesuai dengan besarnya angsuran.

Dalam pengertian lain juga disebutkan, ada beberapa istilah yang berbeda yang diperkenalkan oleh ulama ${ }^{6}$ yaitu Syirkah-mutanaqishah yaitu kerja sama antara para syarik (dalam hal ini bank dengan nasabah) guna membeli suatu barang, kemudian barang tersebut dijadikan "modal usaha"oleh nasabah untuk mendapatkan keuntungan yang akan dibagi bersama di antara bank dengan nasabah disertai dengan pembelian barang modal milik bank yang dilakukan secara berangsur sehingga kepemilikan bank terhadap barang modal semakin lama semakin berkurang $^{7}$, dengan demikian akad ini dinamai musyarakah mutanaqishah karena memerhatikan kepemilikan bank dalam syirkah, yakni penyusutan barang modal syirkah yang dimiliki oleh bank karena dibeli oleh nasabah secara berangsur. Mutanaqishah dalam hal ini berarti penyusutan modal milik bank karena dibayar oleh nasabah dengan cara diangsur.

Gambaran tersebut apabila dilihat dari segi nasabah jumlah barang modal yang dimiliki oleh nasabah semakin lama semakin bertambah karena membeli barang modal milik bank secara berangsur, oleh karena itu, syirkah tersebut dari segi nasabah bukan musyarakah mutanaqishah, tetapi musyarakah ziyadah. ${ }^{8}$

Al-Musyarakah al-Muntahiyyah bit tamlik $^{9}$. Secara bahasa, al-Musyarakah al-Muntahiyyah bit tamlik bearti kerja sama antara sejumlah syarik (dalam hal ini nasabah dengan bank) dengan menyertakan harta untuk dijadikan modal usaha, dan modal usaha syirkah tersebut kemudian dibeli oleh nasabah secara berangsur, sehingga sampai waktu yang dijanjikan, kepemilikan modal bank habis (karena dibeli dengan cara angsuran), seluruh modal usaha syirkah menjadi milik nasabah. Kemudian, musyarakah muqayyadah ${ }^{10}$ yaitu kerjasama terikat, karena dalam

${ }^{8}$ Maulana Hasanudin dan Jaih Mubarok, Perkembangan Akad Musyarakah, Kencana: 2012. Jakarta. Hal. 60-61

${ }^{9}$ Lihat Muhammad 'Abd al-Mun'im Afar. AlIqtishad al-Islami: Dirasat Tathbiqiyyah (Jeddah: Dar al-Bayan al-'Arabi. 1985),vol. II. Hal. 17.

${ }^{10}$ Muhammad Ayub, Understanding Islamic Finance (Jakarta: PT Gramedia Pustaka Utama. 2007), hal. 516 
akad ini terdapat keterikatan yang disepakati oleh bank dan nasabah.

Jadi definisi yang kompleks dari Akad Musyarakah Mutanaqisah (MMq) adalah akad yang terbentuk karena adanya kerjasama antara bank dan pembeli rumah, yang berbagi hak kepemilikan akan sebuah rumah, yang diikuti dengan pembayaran kepemilikan setiap bulannya dan perpindahan kepemilikan sesuai dengan proporsi yang sudah dibayarkan.

\section{Sejarah dan Akar Akad}

\section{Musyarakah Mutanaqishah}

Akad Musyarakah Mutanaqishah merupakan akad hasil kreasi ulama dan pengusaha yang memadukan nilai musyarakah yang terdapat dalam syariah dan kebutuhan instrumen bisnis yang berkembang demikian cepat. Akad ini mulai dirumuskan dan diperkenalkan oleh ulama abad XX M (tepatnya tahun 1997) yang dibahas oleh Majma' al-Fiqhi. ${ }^{11}$

Ulama telah mengidentifikasi Musyarakah Mutanaqishah guna mengetahui asal usulnya secara pasti. Najih Muhammad (1997) dan

${ }^{11}$ Kamal Taufiq Muhammad Hathab, "almusyarakah al-Mutanaqishah ka Adah min Adawat al-Tamwil al-Islami”, dalam Dirasat Iqtishadiyah alIslamiyah (Jedah: al-Bunuk al-Islami litanmiyah alMa'had al-Islami li al-Buhuts wa al-Tadrib. 2003), vol. X, hal 19

\begin{abstract}
Muhammad Ali al-Qari
(1997)

berpendapat bahwa musayarakah mutanaqishah bersumber pada syrikah-milik yang diikuti secara paralel dengan akad jual beli (albai'). ${ }^{12}$
\end{abstract}

\section{Ketentuan Hukum Musyarakah} Mutanaqishah

Fatwa DSN juga disebutkan bahwa hukum Musyarakah Mutanaqishah adalah boleh. Sandaran hukum Islam pada pembiayaan musyarakah mutanaqishah pada saat ini dapat disandarkan pada akad musyarakah (kemitraan) dan ijarah (sewa). Karena didalam akad musyarakah mutanaqishah terdapat unsur syirkah dan unsur ijarah.

Dalam musyarakah mutanaqishah berlaku hukum sebagaimana yang diatur dalam Fatwa DSN No. 08/DSNMUI/IV/2000 ${ }^{13}$ tentang Pembiayaan Musyarakah, yang para mitranya memiliki hak dan kewajiban, diantaranya adalah memberikan modal dan kerja berdasarkan kesepakatan pada saat akad, memperoleh keuntungan berdasarkan nisbah yang disepakati pada saat akad,

${ }^{12}$ Hathab, "al-musyarakah al-mutanaqishah", hal. 19.

13 Lihat Fatwa DSN No. 08/DSNMUI/IV/2000 hal. 1-6. 
menanggung kerugian sesuai proporsi modal.

Berbeda dengan Fatwa DSN No: 73/DSN-MUI/XI/2008, ketentuan akad musyarakah mutanaqishah didalam Fatwa DSN disebutkan terdiri dari akad musyarakah/syirkah dan ba'i (jual beli).

Ketentuan pokoknya dalam Musyarakah Mutanaqishah terdapat unsur kerjasama (syirkah) dan unsur sewa (ujrah). Yakni kerjasama dilakukan dalam hal penyertaan modal atau dana dan kerjasama kepemilikan. Sementara sewa merupakan kompensasi yang diberikan salah satu pihak kepada pihak lain.

\section{Ketentuan Akad ${ }^{14}$}

Pembiayaan Musyarakah adalah pembiayaan berupa akad kerjasama antara pihak BUS/UUS/BPRS dengan pihak Nasabah berupa penyatuan modal oleh masing-masing pihak untuk melaksanakan usaha atau proyek tertentu dan/atau upaya untuk memiliki aset tertentu yang bertujuan untuk memperoleh sejumlah keuntungan dengan ketentuan bahwa keuntungan (profit) dan kerugian

\footnotetext{
${ }^{14}$ Divisi Pengembangan Produk dan Edukasi Departemen Perbankan Syariah Otoritas Jasa Keuangan, Standar Produk Perbankan Syariah "M usyarakah dan Musyarakah Mutanaqishah", hal. 21-23
}

(loss) akan ditanggung bersama. Keuntungan dibagi berdasarkan kesepakatan atau porsi modal sementara kerugian ditanggung hanya sebesar porsi modal masing-masing.

Perjanjian dengan akad Musyarakah harus memenuhi rukun adalah Pihak yang berakad; Bank dan Nasabah dimana keduanya sebagai pemilik modal (Shahibul Maal) sedangkan Nasabah selain sebagai pemilik modal juga sebagai pelaksana (Musyarik), Modal; masing-masing pihak menyertakan modal dengan tujuan untuk membeli suatu aset atau melaksanakan usaha/proyek tertentu, Obyek akad; obyek akad dapat berupa aset, proyek atau usaha yang akan menghasilkan keuntungan bagi para pihak, Ijab Qabul; pernyataan penawaran (ijab) dan penerimaan (qabul) yang dinyatakan oleh para pihak terkait untuk menunjukkan kehendak masing-masing dalam mengadakan perjanjian (akad), Nisbah Bagi Hasil; pembagian porsi keuntungan yang akan diperoleh para pihak dalam bentuk persentase bukan jumlah uang yang tetap.

Pengikatan Perjanjian

Pembiayaan Musyarakah antara BUS/UUS/BPRS dan Nasabah harus dituangkan secara tertulis yang dapat 
dilakukan secara di bawah tangan atau di bawah legalilasi secara notariil.

Dalam Perjanjian Pembiayaan Musyarakah antara BUS/UUS/BPRS dan Nasabah harus dinyatakan secara jelas bahwa kerjasama diantara para pemilik modal dilaksanakan dengan tujuan mencari keuntungan. Dalam Perjanjian Pembiayaan Musyarakah, Nasabah dan BUS/UUS/ BPRS samasama menyediakan modal dan harus dinyatakan dengan tegas perbandingan antara modal BUS/UUS/BPRS dan modal Nasabah.

Pembiayaan Musyarakah yang diberikan BUS/UUS/BPRS dan Nasabah adalah untuk membiayai usaha/proyek/aset tertentu, baik yang sudah berjalan maupun yang baru, yang akan dikelola oleh Nasabah menurut ketentuan yang disepakati oleh BUS/UUS/BPRS. Pembiayaan Musyarakah yang diberikan BUS/UUS/BPRS dapat bersifat kerjasama modal baik dalam jumlah tetap (modal tidak diangsur) maupun jumlah menurun (modal diangsur).

Dalam Pembiayaan Musyarakah jumlah tetap, bagian modal setiap mitra ditentukan sesuai akad dan jumlahnya tetap hingga akhir masa akad, dimana pada akhir masa akad BUS/UUS/BPRS berjanji akan menjual keseluruhan modalnya sekaligus kepada Nasabah dan Nasabah berjanji untuk membeli keseluruhan modal BUS/UUS/BPRS tersebut. Dalam Pembiayaan Musyarakah jumlah menurun, bagian modal BUS/UUS/BPRS akan dijual secara bertahap (diangsur) kepada Nasabah (atau pihak lain) sehingga bagian modal BUS/UUS/BPRS akan menurun dari masa ke masa dan pada akhir masa akad, BUS/UUS/BPRS tidak lagi memiliki modal (menjadi pemilik) dalam usaha/proyek/aset tersebut.

Pengembalian modal dan bagi hasil hak BUS/UUS/BPRS dihitung dan disepakati berdasarkan perjanjian yang dibuat oleh para pihak terkait. Nisbah bagi hasil tidak harus selalu sama setiap bulannya selama masa pembiayaan, walaupun kontribusi modal tetap ataupun juga kontribusi modal menurun, selama hal ini disepakati dari awal dan sudah jelas tertulis pada pembuatan akad. Hal ini tergantung dari perhitungan cash flow atas proyek/usaha yang akan dibiayai.

Jika selama masa kegiatan proyek atau kegiatan usaha dari Pembiayaan Musyarakah terjadi perubahan kontribusi modal sehingga menyebabkan juga perubahan nisbah 
bagi hasil, maka harus dibuatkan addendum (perubahan) atas perjanjian sebelumnya yang disepakati dan ditanda tangani oleh para pihak terkait.

\section{Ketentuan Pihak-pihak Terkait ${ }^{15}$}

Para pihak dalam kontrak Musyarakah adalah pihak yang diperbolehkan yang termasuk ke dalam orang-perorangan dan/atau Perusahaan/Badan Usaha. Para pihak dalam kontrak Musyarakah harus mempunyai kapasitas hukum untuk melaksanakan kontrak. Kontrak Musyarakah harus disertai dengan penawaran (ijab) dan penerimaan (qabul) dari kedua belah pihak.

Salah satu atau kedua belah pihak diperbolehkan melaksanakan kontrak melalui perantara yang sah, dibuktikan dengan surat pernyataan perwakilan yang ditandatangani oleh pihak yang bersangkutan. Para pihak harus terikat oleh ketentuan yang telah disepakati kedua belah pihak dalam kontrak yang mana seluruh ketentuan tersebut tidak ada satu pun yang melanggar kepatuhan prinsip syariah di dalamnya.

\section{Kriteria Nasabah ${ }^{16}$}

Ketentuan kriteria nasabah adalah calon Nasabah adalah pihak yang

${ }^{15}$ Ibid., hal. 23

${ }^{16}$ Ibid., hal. 24-25 diperbolehkan yang termasuk ke dalam orang-perorangan dan/atau Perusahaan/Badan Usaha. calon Nasabah perorangan harus cakap hukum dengan memenuhi ketentuan yang telah diatur dalam pasal 330 KUHPerdata serta bukan pihak yang dikecualikan dalam Pasal 433 KUHPerdata.Calon Nasabah telah melewati proses penilaian dan dikategorikan sebagai Nasabah yang layak dibiayai sesuai kriteria analisa pembiayaan yang sehat.Nasabah yang terikat dalam suatu perkawinan diperlakukan sebagai 1 (satu) Nasabah kecuali terdapat perjanjian pemisahan harta yang dibuat oleh Notaris dan sesuai dengan ketentuan hukum yang berlaku.Perusahaan/Badan Usaha yang akan menjadi Nasabah BUS/UUS/BPRS dapat berbentuk Perusahaan Terbatas, BUMN, BUMD, PMDN, PMA, CV, Koperasi atau Yayasan.Perusahaan/Badan Usaha yang menjadi Nasabah BUS/UUS/BPRS harus telah sah berdiri sebagai badan hukum sesuai dengan standar perundang-undangan yang berlaku yaitu Undang-Undang No. 40 Tahun 2007 untuk Perseroan Terbatas, Undang-Undang Nomor 17 Tahun 2012 untuk Koperasi, UndangUndang Nomor 16 Tahun 2011 
sebagaimana yang telah diubah dari Undang-Undang No. 28 Tahun 2004 untuk Yayasan.Usaha yang dijalankan oleh Perusahaan/Badan Usaha yang akan mengajukan pembiayaan Musyarakah merupakan usaha yang legal serta memenuhi prinsip dan ketentuan syariah.Usaha yang dijalankan oleh Perusahaan/Badan Usaha telah memenuhi syarat terkait dokumen perijinan yang diperlukan seperti Akta Perusahaan yang telah disahkan oleh Institusi Berwenang, NPWP (Nomor Pokok Wajib Pajak) serta kelengkapan dokumen-dokumen perijinan usaha dari Institusi Berwenang.Nasabah perorangan maupun Perusahaan/Badan Usaha tidak tercantum dalam daftar hitam dan daftar kredit macet BI.

\section{Ketentuan Akad Musayarakah Mutanasiqhah $^{17}$}

Pembiayaan MMQ merupakan bentuk pembiayaan kemitraan berbasis bagi hasil antara pihak BUS/UUS/BPRS dan pihak Nasabah dalam rangka kepemilikan suatu aset properti tertentu yang dimiliki bersama berdasarkan prinsip syirkah 'inandimana hishshah(porsi modal)

\footnotetext{
${ }^{17}$ Divisi Pengembangan Produk dan Edukasi Departemen Perbankan Syariah Otoritas Jasa Keuangan, Standar Produk Perbankan Syariah "M usyarakah dan Musyarakah Mutanaqishah", hal. 123-126
}

pihak Bank berkurang dan beralih secara bertahap kepada pihak Nasabah melalui mekanisme pembelian angsuran atau pengalihan secara komersial (bai'). Bagi hasil antara pihak Bank dan pihak Nasabah didasarkan pada hasil penggunaan manfaat atas aset bersama tersebut secara komersial berupa pendapatan ujrohdari penyewaan aset dengan akad ijarah(sewa) sesuai nisbah bagi hasil dan biaya sewa yang disepakati.

Perjanjian dengan akad MMQ harus memenuhi rukun adalah (1) Pihak yang berakad; (2) Bank dan Nasabah keduanya merupakan penyedia dan penyerta modal (Shahibul Maal) dan pemilik properti yang akan disewakan (Mu'jir) sedangkan Nasabah selain sebagai pemilik modal juga bisa sebagai penyewa properti bersama tersebut (Musta'jir). (3) Modal; masing-masing pihak Bank dan Nasabah menyertakan modal dengan tujuan untuk membeli suatu properti tertentu yang akan disewakan kepada Nasabah (atau pihak lain). (4) Obyek akad; obyek akad berupa aset properti yang akan dimiliki bersama, disewakan dan menghasilkan keuntungan bagi para pihak.Ijab Qabul; (5) pernyataan penawaran (ijab) dan penerimaan 
(qabul) yang dinyatakan oleh para pihak terkait untuk menunjukkan kehendak masing-masing dalam mengadakan perjanjian (akad). (6) Nisbah Bagi Hasil; pembagian porsi keuntungan yang akan diperoleh para pihak dalam bentuk persentase bukan jumlah uang yang tetap.

Pengikatan Perjanjian Pembiayaan MMQ antara pihak BUS/UUS/BPRS dan pihak Nasabah harus dituangkan secara tertulis. Perjanjian Pembiayaan MMQ harus menyatakan secara jelas tujuan dilaksanakannya akad diantara para pemilik modal, baik dalam hal kepemilikan aset properti maupun penyewaannya yang bertujuan mencari keuntungan.

Pembiayaan dengan akad MMQ ini diperuntukkan bagi nasabah yang ingin memiliki aset berupa properti dengan berbagai pilihan baik berupa Properti Baru (Ready Stock), Properti Lama (Second) maupun Properti Baru Indent. Jenis properti yang bisa dibiayai adalah rumah tinggal, rumah susun (rusun), rumah toko (ruko), rumah kantor (rukan), apartemendan kondominium.

Dalam Perjanjian Pembiayaan MMQ, Nasabah dan BUS/UUS/BPRS sama-sama menyediakan modal dan harus dinyatakan dengan tegas perbandingan antara modal BUS/UUS/BPRS dan modal Nasabah.Pembiayaan MMQ yang diberikan BUS/UUS/BPRS bersifat kerjasama dalam bentuk jumlah modal menurun (diminishing musharakah). Dalam akad MMQ ini bagian modal BUS/UUS/BPRS akan dijual secara bertahap kepada Nasabah (atau pihak lain) sehingga bagian modal BUS/UUS/BPRS akan menurun dari masa ke masa dan pada akhir masa akad, BUS/UUS/BPRS tidak lagi memiliki modal dan Nasabah akan berjanji membeli seluruh hishshah(porsi) BUS/UUS/BPRS sehingga Nasabah menjadi pemilik atas keseluruhan aset tersebut.

Pembelian atau pengalihan komersial hishshah(porsi) BUS/UUS/BPRS kepada Nasabah harus dihitung dan dilakukan secara jelas dengan mekanisme yang disepakati dalam kontrak. Dalam Pembiayaan MMQ, Nasabah mengembalikan modal disertai bagi hasil yang telah disepakati secara bertahap sesuai kontrak yang telah disepakati.

Nasabah dapat menggunakan bagi hasil yang menjadi haknya untuk digunakan sebagai pembayaran kepada 
BUS/UUS/BPRS sebagai pembelian atau pengalihan komersial hishshah (porsi) atas aset yang dimiliki bersama sehingga secara bertahap hishshah (porsi) Nasabah meningkat.

Nisbah bagi hasil, harga unit hishshah, maupun harga sewa obyek MMQ tidak harus selalu sama setiap bulannya selama masa pembiayaan, selama hal ini disepakati dari awal dan sudah tertulis jelas pada kontrak. Perubahan ini tergantung pada perhitungan nilai aset yang berlaku (market real price).

\section{Plafond Pembiayaan dan FTV ${ }^{18}$}

Plafond pembiayaandan FTV adalah pertama, BUS/UUS/BPRS berhak menentukan batasan plafond pembiayaan yang akan diberikan kepada Nasabah menurut kebijakan BUS/UUS/BPRS masingmasing.Kedua, Maksimum plafond pembiayaan adalah sesuai kebutuhan namun tidak melebihi collateral coverage jaminan saat pengajuan pembiayaan serta sesuai standar perhitungan Financing to Value (FTV) dan ketentuan yang berlaku.Ketiga, Financing to Value (FTV) adalah

${ }^{18}$ DivisiPengembangan Produk dan Edukasi Departemen Perbankan Syariah Otoritas Jasa Keuangan, Standar Produk Perbankan Syariah "M usyarakah dan Musyarakah Mutanaqishah", hal. 132-135 perbandingan antara jumlah pembiayaan (F) dengan harga jual atau hasil penilaian, mana yang lebih rendah (V).Keempat, Rasio penghitungan Financing To Value (FTV) dapat digunakan sebagai salah satu alat untuk memberikan keputusan pembiayaan.Kelima, Penetapan Financing To Value (FTV) bertujuan untuk meyakinkan bahwa properti yang dibiayai memiliki nilai agunan yang memadai yang dapat menutup sisa pembiayaan jika terjadi eksekusi di kemudian hari dan melindungi konsumen atas kewajaran harga jual.Jika Perjanjian Pembiayaan yang dilakukan para pihak mengikat lebih dari 1 (satu) unit properti pada saat bersamaan dan/atau mengikat beberapa perjanjian terhadap beberapa properti pada tanggal yang sama, maka perhitungan FTV diberlakukan dengan ketentuan berikut: BUS/UUS/BPRS wajib menetapkan urutan fasilitas pembiayaan berdasarkan urutan nilai agunan dimulai dari nilai agunan yang paling rendah; (2) Penentuan urutan pembiayaan harus memperhitungkan seluruh fasilitas pembiayaan properti atau KPR yang telah atau sedang diterima Nasabah di BUS/UUS/BPRS yang sama maupun BUS/UUS/BPRS 
lainnya;

BUS/UUS/BPRS

memberitahukan penentuan urutan fasilitas pembiayaan kepada Calon Nasabah secara tertulis.Keenam, Jika BUS/UUS/BPRS memberikan fasilitas pembiayaan tambahan dari fasilitas pembiayaan yang masih berjalan atau fasilitas pembiayaan baru berdasarkan properti yang masih menjadi agunan dari fasilitas pembiayaan properti atau KPR iB sebelumnya maka berlaku ketentuan sebagai berikut (1)Pemberian fasilitas pembiayaan tersebut diperlakukan sebagai pemberian pembiayaan baru; (2)Perhitungan FTV diperlakukan sebagai urutan fasilitas pembiayaan berikutnya; dan (3) Jumlah fasilitas pembiayaan tambahan atau pembiayaan baru berdasarkan properti yang menjadi agunan dari fasilitas pembiayaan properti atau KPR iB sebelumnya yang diberikan oleh BUS/UUS/BPRS paling banyak sebesar selisih antara hasil perhitungan FTV berdasarkan nilai properti yang menjadi agunan dengan baki debet dari fasilitas pembiayaan sebelumnya yang menggunakan agunan yang sama.

\section{Skema Pembiayaan Musyarakah Mutanaqishah}

Kita lihat bagan alur pembiayaan musyarakah mutanaqishah dibawah ini

\section{Skema 1}

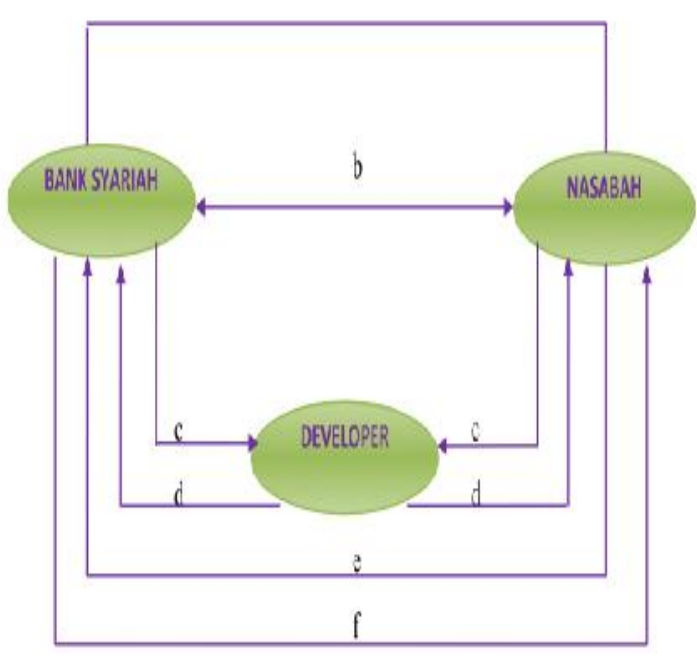

Keterangan:

a. Negoisasi angsuran dan sewa

b. Akad kerjasama

c. Beli barang, bisa bank atau nasabah

d. Mendapat berkas dan dokumen

e. Nasabah membayar angsuran sewa

f. Lembaga keuangan syariah menyerahkan hak kepemilikannya.

Ada beberapa tahapan dalam pembiayaan musyarakah mutanaqishah untuk pengadaan suatu barang, yakni: ${ }^{19}$ tahap pertama, Nasabah mengajukan permohonan kepada bank untuk menjadi mitra dalam pembiayaan/pembelian suatu

19 Makalah diskusi, Musyarakah Mutanaqishah, M. Nadratuzzaman Hosen, seorang Doktor lulusan Australia dosen tetap di Fakultas Syariah dan Hukum dengan Jabatan Akademik Lektor, pangkat pembina/iva di KPP IPB Bogor 
barang yang dibutuhkan nasabah dengan menjelaskan data nasabah, diantaranya berkaitan dengan pendapatan perbulan nasabah, sumber pengembalian dana untuk pelunasan kewajiban nasabah, serta manfaat dan tingkat kebutuhan nasabah atas brang tersebut. Pengajuan permohonan dilengkapi dengan persyaratan administratif pengajuan pembiayaan yang berlaku pada masing-masing bank dan telah ditentukan dalam pembiayaan syariah.Tahap kedua, Petugas lembaga keuangan syariah biasa disingkat LKS akan menganalisa kelayakan nasabah untuk mendapatkan barang tersebut secara kualitatif atau kuantitatif.Tahap ketiga,Apabila permohonan nasabah layak disetujui oleh komite pembiayaan, maka LKS menerbitkan surat persetujuan pembiayaan (offering letter) yang didalamnya adalah (a) Spesifikasi barang yang disepakati, (b) Harga barang, (c) Jumlah dana bank dan dana nasabah yang disertakan, (d) Jangka waktu pelunasan pembiayaan, (e) Cara pelunasan (model angsuran), Besarnya angsuran dan biaya sewa yang dibebankan nasabah.

Tahap kedua, Apabila nasabah menyetujui persyaratan yang dicantumkan dalam offering letter tersebut, maka pihak LKS dan/atau nasabah dapat menghubungi distributor agen untuk ketersediaan barang tersebut sesuai dengan spesifikasinya.

Tahap Ketiga, Kemudian yang terakhir dilakukan akad musyarakah mutanaqishah anatara LKS dan nasabah yang memuat persyaratan penyertaan modal (kemitraan), persyaratan sewa menyewa dan sekaligus pengikatan jaminan berupa barang yang diperjualbelikan tersebut serta jaminan tambahan lainnya.

Penyerahan barang dilakukan oleh distributor/agen kepada LKS dan nasabah, setelah LKS dan nasabah, melunasi harga pembelian barang kepada distributor/agen. Setelah barang diterima LKS dan nasabah, pihak LKS akan melanjutkan menyerahkan barang tersebut kepada pihak nasabah dengan menerbitkan surat tanda terima barang dengan penjelasan spesifikasi barang yang telah disepakati. 
Skema 2

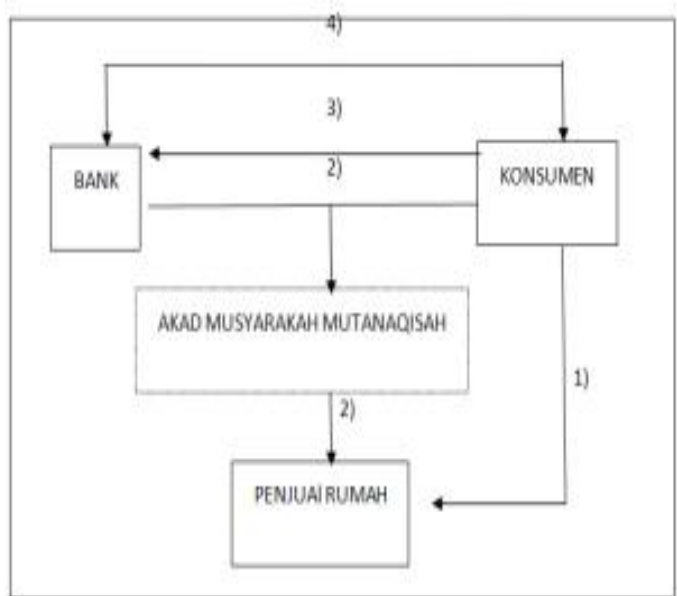

Misal Perhitungan dari skema diatas dapat digambarkan didalam contoh berikut. Misalkan penjual rumah hendak menjual rumahnya di harga Rp.100,000,000. Dan ada seorang pembeli $\mathrm{B}$ yang ingin membeli rumah tersebut dengan mengajak Bank A untuk bermitra melalui akad MM.

Maka kontrak pertama yang dilakukan adalah dimana Bank A harus mengadakan perjanjian kemitraan (Musyarakah) dengan pembeli B untuk membeli rumah. Misalkan Bank A membeli rumah dengan harga Rp.80,000,000 dan pembeli $\mathrm{B}$ membayar rumah tersebut pada harga Rp.20,000,000. Maka proporsi kepemilikan rumah tersebut adalah $80 \%$ Bank A, dan $20 \%$ adalah konsumen. Dan setiap bulannya, pembeli B akan melakukan pembelian kepemilikan dari Bank A sebesar Rp.500,000.

Kontrak yang berikutnya adalah kontrak Ijarah diantara Bank A dengan pembeli B, dimana pembec $\mathrm{B}$ melakukan pembayaran sewa kapada Bank A setiap bulannya, misalkam pada harga Rp.500,000. Dari Rp.500,000 ini, akan dibagi berdasarkan proporsi kepemilikan. Jika proporsi Bank A $80 \%$, maka dari uang sewa yang pertama, bank akan mendapat upah sewa sebesar Rp. 400,000. Dan konsumen akan mendapat Rp. 100,000, dengan proporsi kepemilikan hanya $20 \%$.

\section{Gambar 1}

\section{Musyarakah Mutanaqisah-2}

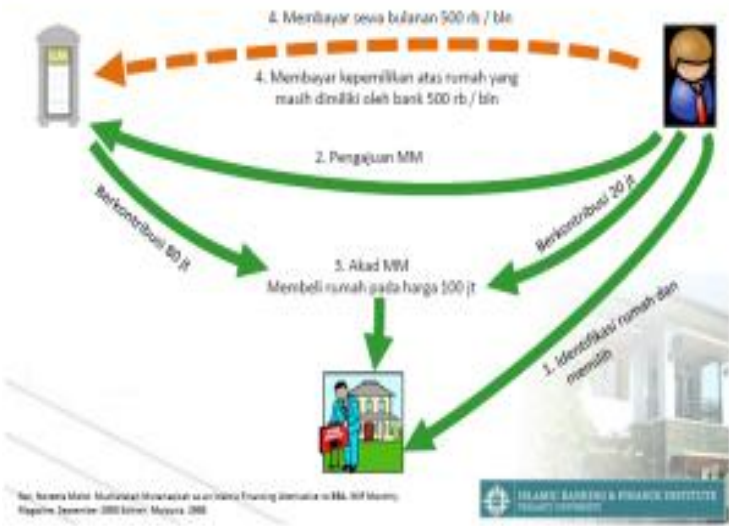

10. Kelebihan

dan

Kelemahan Pembiayaan

\section{Musyarakah}

\section{Mutanaqishah $^{20}$}

Ada beberapa kelebihan pembiayanmusyarakah mutanaqishah adalah (a) LKS dan nasabah samasama memiliki atas suatu aset yang menjadi objek perjanjian. Karena

${ }^{20} \mathrm{Ibid}$. 
merupakan aset bersama maka antara LKS dan nasabah akan saling menjaga atas aset tersebut. (b) Adanya bagi hasil yang diterima antara kedu belah pihak atas margin sewa yang telah ditetapkan atas aset tersebut. (c) Kedua belah pihak dapat menyepakati adanya perubahan harga sewa sesuai dengan waktu yang telah ditentukan dengan mengikuti harga pasar. (d) Dapat meminimalisir risiko financial cost jika terjadi inflasi dan kenaikan suku bunga pasar pada perbankan konvensional. (e) Tidak terpengaruh pada terjadinya fluktuasi bunga pasar pada bank konvensional, dan atau fluktuasi harga saat terjadinya inflasi.

$$
\text { Kemudian ada beberapa }
$$

kelemahan yang muncul dalam akad musyarakah mutanaqishahketika diterapkan sebagai bentuk pembiayaan syariah adalah risiko terjadinya pelimpahan atas beban biaya transaksi dan pembayaran pajak, baik pajak atas hak tanggungan atau pajak atas bangunan, serta biaya-biaya lain yang mungkin akan menjadi beban atas aset tersebut, dan berkurangnya pendapatan LKS atas margin sewa yang dibebankan pada aset yang menjadi objek akad.

\section{Status Kepemilikan Modal Usaha Syirkah}

Ulama Malikiyah, antara lain Ibn Rusyd berpendapat bahwa akad syirkah termasuk akad yang dibolehkan dan termasuk akad gair lazim (akad yang tidak menyebabkan beralihnya kepemilikan benda. Oleh karena itu, dalam pandangan jumhur ulama bahwa dana yang disertakan oleh syarik sebagai modal usaha bersama tetap berkedudukan sebagai milik syarik (tidak berpindah kepada pihak lain). Dampak hukumnya antara lain adalah bahwa setiap syarik berhak membatalkan akad syirkah dengan syarat pembatalan akad oleh salah satu syarik diketahui syarik dan/atau para syarik lainnya. $^{21}$

\section{Berakhirnya Syirkah}

Meskipun pakar hukum diantaranya R. Setiawan menegaskan bahwa perikatan tidak sepenuhnya sama dengan perjanjian, ${ }^{22}$ akan tetapi yang dibahas dalam penelitian ini adalah syirkah sebagai perikatan, yaitu perjanjian para syarik untuk melakukan syirkah dan disepakati

${ }^{21}$ Wahbah al-Zuhaili, al-Fiqh al-Islami wa Adillatuh, (Damaskus: Dar al-Fikr, 2006), vol. V, hal 394.

${ }^{22}$ Handri Raharjo, Hukum Perjanjian di Indonesia, (Yogyakarta: Pustaka Yustisia. 2009), hal. 95. 
bersama sehingga mengikat para syarik yang ber-syirkah. ${ }^{23}$

Dalam hal ini penting untuk diketahui penjelasan pakar hukum Islam, antara lain Fatcurrahman Djamil, yang menyatakan bahwa berakhirnya akad/intiha' al-'aqd karena tiga hal: 1) berakhirnya masa berlaku akad, 2) dibatalkannya akad oleh pihak-pihak yang berakad, dan 3) salah satu pihak yang berakad meninggal dunia. ${ }^{24}$

\section{KESIMPULAN}

Pada skema konvensional dan murabahah, sering kita temui tingkat harga cicilan barang yang menentukan tingkat keuntungan suatu bank. Cicilan ini dipengaruhi oleh harga pokok barang, harga barang yang dibeli nasabah, lamanya cicilan dan besarnya DownPayment (DP).

Dalam kaitannya misalnya dengan harga sebuah rumah, ada survey dari suatu lembaga bahwa masyarakat, menginginkan cicilan bersifat flat (tetap), DP sebesar 15\% dari harga rumah/barang dan cicilan tidak lebih besar dari $20 \%$ pendapatan.

23 Lihat Henry Pandapotan Panggabean, Peranan Mahkamah Agung Melalui Putusan-Putusan Hukum Perikatan (Bandung: PT Alumni. 2008), hal. 74.

${ }^{24}$ Fatchurrahman Djamil, "Hukum Perjanjian Syariah", dalam Badrulzaman dkk, Kompilasi Hukum, hal. 259
Dengan penerapan skema musyarakah mutanaqishah cocok untuk waktu yang panjang melebihi 10 tahun pelunasan. Bagi bank, keuntungan didapat bukan dari nilai cicilan tapi nilai sewanya. Dengan waktu yang panjang nilai cicilan akan rendah sedangkan sewa bisa disesuaikan untuk kurun waktu tertentu.

\section{DAFTAR PUSTAKA}

Atang Abdul Hakim, Fiqh Perbankan Syariah: Transformasi Fiqh Muamalah ke dalam Peraturan Perundang-undangan, (Bandung: Refika Aditama, cetakan kesatu September 2011).

Ascarya, Akad dan Produk Bank Syariah, (Jakarta:Raja Grafindo Persada, cetakan ke III 2011)

Divisi Pengembangan Produk dan Edukasi Departemen Perbankan Syariah Otoritas Jasa Keuangan, Standar Produk Perbankan Syariah "Musyarakah dan Musyarakah Mutanaqishah"

Fatchurrahman Djamil, "Hukum Perjanjian Syariah", dalam Badrulzaman dkk, Kompilasi Hukum.

Fatwa DSN. Musyarakah Mutanaqishah Hathab, "al-musyarakah al-mutanaqishah"

Henry Pandapotan Panggabean, Peranan Mahkamah Agung Melalui PutusanPutusan Hukum Perikatan (Bandung: PT Alumni. 2008).

Kamal Taufiq Muhammad Hathab, "almusyarakah al-Mutanaqishah ka Adah min Adawat al-Tamwil al-Islami”, dalam Dirasat Iqtishadiyah alIslamiyah (Jedah: al-Bunuk al-Islami 
litanmiyah al-Ma'had al-Islami li alBuhuts wa al-Tadrib. 2003), vol. X.

Maulana Hasanudin dan Jaih Mubarok, Perkembangan Akad Musyarakah, Kencana: 2012. Jakarta.

Muhammad Mushthafa Abruh al-Syinqithi, Dirasah Syar'iyyah li Ahammi al'Uqud al-Maliyah al-Mustahdatsah (Madinah: Maktabat al-Ulum wa alHikkam. 2001), vol I.

Muhammad 'Abd al-Mun'im Afar. AlIqtishad al-Islami: Dirasat Tathbiqiyyah (Jeddah: Dar al-Bayan al-'Arabi. 1985), vol. II.

Muhammad Ayub, Understanding Islamic Finance (Jakarta: PT Gramedia Pustaka Utama. 2007).

Wahbah al-Zuhaili, al-Fiqh al-Islami wa Adillatuh, (Damaskus: Dar al-Fikr, 2006), vol. V.

http://keuangansyariah.mysharing.co/inikeunggulan-akad-musyarakahmutanaqisah/

(13 April 2016 pukul 11.20 wib)

http://keuangansyariah.mysharing.co/inikeunggulan-akad-musyarakahmutanaqisah/ (13 April 2016 pukul $11.30 \mathrm{wib})$ 